\title{
Developing breeding and deployment options for Douglas-fir in New Zealand: breeding for future forest conditions
}

\author{
By H. S. DungeY*), C. B. Low, J. Lee, M. A. Miller, K. Fleet and A. D. Yanchuk
}

Scion, Te Papa Tipu Innovation Park, 49 Sala Street, Private Bag 3020, Rotorua, 3046, New Zealand

(Received 12 $2^{\text {th }}$ May 2011)

\begin{abstract}
Genetic improvement of Douglas-fir in New Zealand was initiated in 1955 with large provenance trials established in the late 1950's. These trials illustrated that material from the coast of Oregon and California grew faster than other provenances tested. Further collections were made to evaluate provenance and familylevel performance from these two areas, and in 1996 additional trials were established at four low-altitude sites across New Zealand.

Genotype $\times$ environment $(\mathrm{GxE})$ interaction among these sites was found to be important for diameter at breast height (DBH), less important for stem straightness and malformation and not important for outerwood acoustic velocity (a surrogate for wood stiffness). Heritabilities were low to moderate for all growth traits, and very low for malformation. Heritability for needle cast due to Swiss needle cast, measured as needle retention on the one site where infection was relatively high, was moderate at 0.37 , and was likely a major factor creating GxE interactions for growth among sites. The heritability of wood acoustic velocity was moderate to high at individual sites $(0.26-0.74)$ and across sites $(0.49)$. Individual-trait selection revealed the potential for good genetic gains to be made when selecting the top 20 families for diameter growth (an average of $10.7 \%$ ), straightness (an average of $11.5 \%$ ) and acoustic velocity (an average of $7.0 \%$ ).

When we examined predicted genetic gains while selecting for needle retention and/or $\mathrm{DBH}$, we found that selecting for needle cast at the affected site did not compromise DBH gains at that site. Selecting for genotypes with low needle cast at the affected site did, however, reduce gains for $\mathrm{DBH}$ estimated across all sites. In order to maximise gains across the current Douglas-fir growing estate, a division of growing sites between those known and predicted to be affected by needle cast and those not affected would seem appropriate. This is particularly relevant given recent climate modelling work suggests that Swiss needle cast will become more important in the South Island, and even more destructive in the North Island of New Zealand. We suggest addressing differences in site through the development of separate deployment populations.
\end{abstract}

Key words: Pseudotsuga menziesii; tree breeding; deployment; genotype x environment interaction; Swiss needle cast.

\footnotetext{
*) Corresponding Author: Heidi Dungey. Scion, Te Papa Tipu Innovation Park, 49 Sala Street, Private Bag 3020, Rotorua, 3046, New Zealand. DDI +64-7-3435629, FAX +64-7-3480952 E-Mail: heidi.dungey@scionresearch.com
}

\section{Introduction}

Douglas-fir (Psuedotsuga menziesii [Mirb.] Franco) is planted on approximately 110 thousand hectares in New Zealand and is the second most important exotic softwood after Pinus radiata D. Don (MINISTRY OF AGRICULTURE AND Forestry, 2011; Miller and KNOWLES, 1994; Shelbourne et al., 2007). Planted Douglas-fir has wood properties that are well suited for structural purposes, and in New Zealand the timber is also rated as Class 3 durable, suitable for above-ground and interior purposes (Cown, 1976; KNowles et al., 2004; NZ WoOD, 2011). Genetic improvement of the species has therefore been aimed at improving growth, form and more recently, wood stiffness. It is expected that improving the wood properties of New Zealand-grown Douglas-fir will improve the utilisation and output of more valuable lumber within higher structural grades.

Genetic improvement of Douglas-fir in New Zealand was initiated in 1955 by I.J. Thulin (SwEET, 1965). Large provenance trials of 35 and 45 provenances were established in 1957 and 1959, on eight and 19 sites, respectively. Origin of the material was from Washington and Oregon (1957), with a limited number of provenances from Californian and Oregon coastal populations (1959). Analyses at age five showed that Oregon and California-origin material from coastal areas was growing faster than other provenances, so additional collections were made from these two areas (SHELBOURNE et al., 2005). In 1996, following the formation of a new research cooperative for Douglas-fir, three additional breeding trials (open-pollinated seedlots from the 1996 collections were established (SHELBOURNE et al., 2005; SHELBOURNE et al., 2007).

Douglas-fir in New Zealand can be badly affected by Swiss needle cast (SNC) (HooD et al., 1990; KNOWLES et al., 2001). This foliage disease, caused by Phaeocryptopus gaeumannii (Rohde) Petrak, is widely distributed in New Zealand plantations, and both pathogen abundance and disease severity have been shown to be associated with mild mean daily winter temperatures (August minimum and June average) and spring moisture (STONE et al., 2007). Swiss needle cast has serious implications for the New Zealand Douglas-fir breeding population, for example, the need for selection of resistant genotypes for the North Island, and the consideration of separate selections for the South Island, in areas where the disease is not as prevalent. Knowing that SNC was not the only contributing factor to growth differences among provenances (HOOD and KIMBVERLEY, 2005), a thorough 
investigation of genotype $\times$ environment interaction was needed to determine the impact of selections for regional deployment.

Climate change in New Zealand is projected to have a number of different effects that will be important over the next rotation, and possibly affect the development of improved germplasm and deployment strategies. In New Zealand, mean annual temperature is projected to increase 0.9 degrees celsius by 2040 and by 2.1 degrees celsius by 2090 (WRATT and MULLAN, 2010). Rainfall is projected to increase on the south-west of the South Island, and decrease on the east cost of both the South and North Islands. Rather than dramatically affecting the growth of Douglas-fir, climate change may affect dynamics of pests and diseases that affect Douglas-fir. The recent widespread mortality of lodgepole pine by bark beetles in British Columbia and Alberta, Canada (KURZ et al., 2008; SAFRANYIK et al., 2010; CUDMORE et al., 2010; SHORE et al., 2004; MACiAS FAURIA and JoHNSON, 2009), as well as serious local outbreaks in needle diseases (WoODS et al., 2005; MAGUIRE et al., 2011; HANSEN et al., 2000), has clearly demonstrated the effects that climate change can have on forests.

Current-climate spatial predictions of foliage retention/tolerance to SNC in Douglas-fir for the North and South Islands of New Zealand are between 70-100\% and 40-70\% respectively (WATT et al., 2010). Using 12 different Global Climate Models and three different emission scenarios (low, medium and high), the impact of the distribution of foliage retention to 2090 was predicted to be substantial with lower foliage retention and potential volume growth losses up to a $50 \%$ in warmer areas (WATT et al., 2010). The amount of predicted damage on Douglas-fir in the warmer areas of the North Island may make further planting of this species in this area untenable. Currently, seed collections for some tolerance to SNC damage is occurring for plantations on the South Island (i.e., little disease is present), and selection for resistance to the needle disease is largely by default from North Island sites - i.e. the fastest growing trees selected on North Island sites are generally those trees with fewer symptoms of the disease.

Here, we examine the 1996 series of trials and report on 1) the levels of genetic variation present in diameter growth, stem malformation and straightness, outerwood acoustic velocity, and needle retention in the presence of SNC at one site, 2) the genotype $\mathrm{x}$ site interactions among these traits and 3) suggest options for breeding and deployment of Douglas-fir in New Zealand in the context of the current impacts of SNC, and those projected with climate change.

\section{Methods \\ Genetic material}

In 1996 three breeding trials were established at Golden Downs, near Nelson, Kaingaroa in the Central North Island, and Gowan Hill, in Southland, with a small site at Manuka Awa, in Southland/Otago. Details of the genetic material in these trials are described in Tables 1 and 2. For the purposes of analysis, Usal Road, with only 1 family, was included in the Rockport provenance and; Coquille (2 families) was included in Myrtle Point.

\section{Trial design and location}

All trial locations and site information are given in Table 3 and Figure 1. The trial design for the three main sites Golden Downs, Gowan Hill and Kaingaroa was a sets-in-replicates, single-tree-plot design. Each of the three main trials comprised 30 replicates, with 7 sets within each replicate and 34 families +2 controls per set. The provenances were evenly represented across sets. The Manuka Awa trial was established from residual trial stock in 1996. The design at Manuka Awa was 88 families plus 19 seedlots in five replicates of 5 -tree row plots. Spacing was $3 \times 3 \mathrm{~m}$ for all trials.

\section{Assessments}

Traits assessed are shown in Table 4.

Table 1. - Genetic material included in the 1996 Douglas-fir trials across three sites. A sub-set of this material was also planted at Manuka Awa.

\begin{tabular}{|c|c|c|c|c|c|}
\hline Provenance/seedlot & $\begin{array}{c}\text { No. } \\
\text { families }\end{array}$ & Latitude & Provenance/seedlot & $\begin{array}{c}\text { No. } \\
\text { families }\end{array}$ & Latitude \\
\hline Los Padres & 6 & $35^{\circ} 49^{\prime}$ & Brookings & 7 & $42^{\circ} 06^{\prime}$ \\
\hline S. P. Taylor & 10 & $38^{\circ} 02^{\prime}$ & Ophir & 3 & $42^{\circ} 36^{\prime}$ \\
\hline Pt. Reyes & 10 & $38^{\circ} 04^{\prime}$ & Myrtle Point & 9 & $43^{\circ} 06^{\prime}$ \\
\hline Russian River & 10 & $38^{\circ} 25^{\prime}$ & Coquille & 2 & $43^{\circ} 13^{\prime}$ \\
\hline Fort Ross & 10 & $38^{\circ} 31^{\prime}$ & Coos Bay & 11 & $43^{\circ} 20^{\prime}$ \\
\hline Gualala & 9 & $38^{\circ} 47^{\prime}$ & Umpqua River & 24 & $43^{\circ} 34^{\prime}$ \\
\hline Navarro River & 13 & $39^{\circ} 11^{\prime}$ & Swanton & 3 & $37^{\circ} 06^{\prime}$ \\
\hline Noyo River & 20 & $39^{\circ} 25^{\prime}$ & Cascade Ranch & 12 & $37^{\circ} 08^{\prime}$ \\
\hline Rockport & 5 & $39^{\circ} 41^{\prime}$ & SF Water Reserve & 19 & $37^{\circ} 27^{\prime}$ \\
\hline Usal Road & 1 & $39^{\circ} 49^{\prime}$ & Willamette Forest & 10 & $43^{\circ} 50^{\prime}$ \\
\hline Arcata & 15 & $39^{\circ} 59^{\prime}$ & Siuslaw Forest & 21 & $44^{\circ} 10^{\prime}$ \\
\hline
\end{tabular}


Table 2. - Origin of the control seedlots used in the 1996 trial series.

\begin{tabular}{|c|c|}
\hline Provenance & Origin \\
\hline Fort Bragg, CA & Seed Stand Compartment 55, Rotoehu Forest \\
\hline Fort Bragg, CA & Compartment 1132, Kaingaroa forest $\left(2^{\text {nd }}\right.$ generation ex Rotoehu) \\
\hline Washington & Compartment 1061, Kaingaroa ( $3^{\text {rd }}$ generation in New Zealand) \\
\hline Fort Bragg,CA & Seed Stand Compartment 115, Golden Downs Forest \\
\hline Oregon & Seed Stand Eyrewell Forest ( $2^{\text {nd }}$ generation ex Ashley) \\
\hline Oregon & Seed Stand Mount Thomas Forest ( $2^{\text {nd }}$ generation ex Ashley) \\
\hline Washington & Seed stand Beaumont Forest \\
\hline Arcata, CA & Louisiana-Pacific Seed Orchard, Humboldt County, California \\
\hline US Weyerhaeuser \#1 & Coos Bay, Oregon \\
\hline US Weyerhaeuser \#1 & Long View, Washington \\
\hline US Weyerhaeuser \#1 & Twin Harbours, Washington \\
\hline US Weyerhaeuser \#2 & Coos Bay, Oregon \\
\hline US Weyerhaeuser \#2 & Long View, Washington \\
\hline US Weyerhaeuser \#2 & Washington, Twin Harbours \\
\hline US Weyerhaeuser \#3 & Coos Bay, Oregon \\
\hline US Weyerhaeuser \#3 & Long View, Washington \\
\hline US Weyerhaeuser \#3 & Twin Harbours, Washington \\
\hline US Weyerhaeuser \#4 & Coos Bay, Oregon \\
\hline US Weyerhaeuser \#4 & Long View, Washington \\
\hline US Weyerhaeuser \#4 & Twin Harbours, Washington \\
\hline
\end{tabular}

Needle retention was scored only at Kaingaroa, at age 7 , as it was considered to be the site where needlecast would be most prevalent and symptoms were not expressed at the other sites. Acoustic velocity was measured as a surrogate of wood stiffness (VEL) and was only measured on the top 60 families for DBH at each site, regardless of provenance sampled and was not measured at Manuka Awa.

\section{Analysis}

Means and linear models

Least-squares means, coefficients of variation and comparisons among provenance means were undertaken using PROC GLM of the SAS statistical package (SAS InSTITUTE, 2010). There was not enough variation in malformation at Golden Downs to warrant analysis so no further in-depth genetic analysis was undertaken on this trait.

Genetic parameter estimates and breeding values, at single sites used model [1], and across sites, model [2], using ASReml (GILmour et al., 2010). Controls were excluded for all variance component estimations.

$$
Y_{i j k l}=\mu+P_{i}+R_{j}+F(P)_{i k}+\varepsilon_{i j k l}
$$

Where $Y_{i j k l}$ is the individual-tree observation, $P_{i}$ is the fixed effect of the $\mathrm{i}^{\text {th }}$ provenance, $R_{j}$ is the random effect of the $\mathrm{j}^{\text {th }}$ replicate, $F(P)_{i k}$ is the random effect of the $\mathrm{k}^{\text {th }}$ family within the $\mathrm{i}^{\text {th }}$ provenance, and $\varepsilon_{i j k l}$ is the residual error. At Manuka Awa, an additional term of $F(P) \times R_{i j k}$ was used, as this trial had 5-tree plots.

Across the three main sites (Kaingaroa, Golden Downs and Gowan Hill), the model used was:

$$
\begin{aligned}
Y_{i j k l m}= & \mu+S_{i}+P_{j}+R(S)_{i k}+F(P)_{j l}+ \\
& P \times S_{i j}+F(P) \times S_{i j l}+\varepsilon_{i j k l m}
\end{aligned}
$$

Where $Y_{i j k l m}$ is the individual-tree observation, $S_{i}$ is the fixed effect of the $\mathrm{i}^{\text {th }}$ site, $P_{j}$ is the fixed effect of the $\mathrm{j}^{\text {th }}$ provenance, $R(S)_{i k}$ is the random effect of the $\mathrm{k}^{\text {th }}$ replicate within the $\mathrm{i}^{\text {th }}$ site, $F(P)_{j l}$ is the random effect of

\begin{tabular}{|c|c|c|c|c|c|c|c|c|c|c|c|c|c|c|}
\hline Trial site & Latitude & Longitude & Elevation & Aspect & 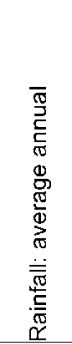 & 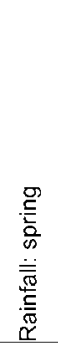 & 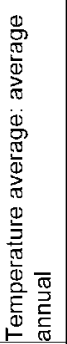 & 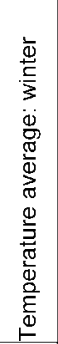 & 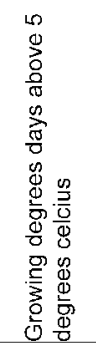 & 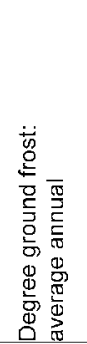 & 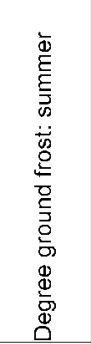 & 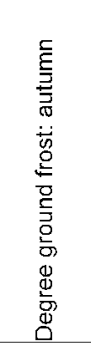 & 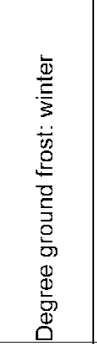 & 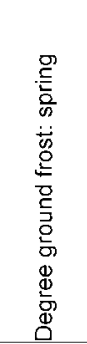 \\
\hline & (S) & (E) & $M$ & & $\mathrm{~mm}$ & $\mathrm{~mm}$ & ${ }^{\circ} \mathrm{C}$ & ${ }^{\circ} \mathrm{C}$ & ${ }^{\circ} \mathrm{C}$ & N.days & N.days & N.days & N.days & N.days \\
\hline Kaingaroa & $38^{\circ} 1700.00$ & $176^{\circ} 4400.00$ & $300 \mathrm{~m}$ & $E$ & 1716 & 133 & 12.1 & 7.1 & 2572.0 & 6.5 & 0.6 & 5.4 & 14.3 & 5.8 \\
\hline Golden Downs & $41^{\circ} 2800.00$ & $172^{\circ} 5200.00$ & $350 \mathrm{~m}$ & $N E, S E, W$ & 1344 & 113 & 10.2 & 5.1 & 1914.0 & 8.6 & 0.7 & 7.0 & 19.4 & 7.4 \\
\hline Gowan Hill & $45^{\circ} 5200.00$ & $168^{\circ} 0700.00$ & $230 \mathrm{~m}$ & Multiple & 900 & 72 & 9.5 & 4.7 & 1683.0 & 9.4 & 1.7 & 7.6 & 19.6 & 8.7 \\
\hline Manuka Awa & $45^{\circ} 5230.31$ & 168459.18 & $255 \mathrm{~m}$ & WSW & 816 & 65 & 8.8 & 4.2 & 1579.0 & 6.6 & 0.6 & 4.3 & 15.7 & 6.0 \\
\hline
\end{tabular}
the $\mathrm{l}^{\text {th }}$ family within the $\mathrm{j}^{\text {th }}$ provenance, $+P \times S_{i j}$ is the

Table 3. - Individual site details. 


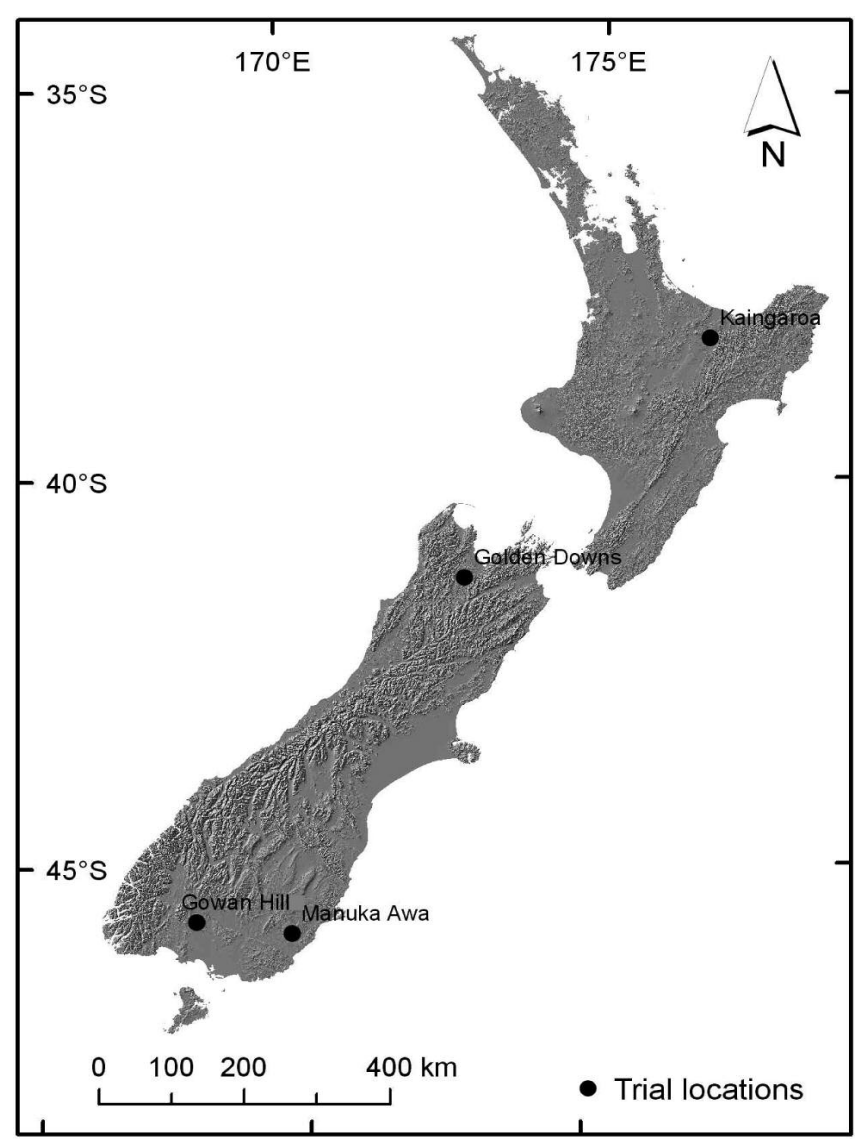

Figure 1. - Locations of the Douglas-fir progeny trials. The 1996 trial series was established at Kaingaroa, Golden Downs, Gowan Hill, with a subset of families at Manuka Awa.

random interaction between the $\mathrm{j}^{\text {th }}$ provenance across the $\mathrm{i}^{\text {th }}$ site, $F(P) \times S_{i j l}$ is the random interaction between the $\mathrm{l}^{\text {th }}$ family within the $\mathrm{j}^{\text {th }}$ provenance across the $\mathrm{i}^{\text {th }}$ site, and $\varepsilon_{i j k l m}$ is the residual error.

Significance of effects in the model were tested using the log ratio test (GILMOUR et al., 2010):

$$
D=2\left[\log \left({ }^{` R} 2\right)-\log \left({ }^{` R} 1\right)\right]
$$

Where log'R1 is the REML log-likelihood of the restricted model and log $\mathrm{R} 2$ is the REML log-likelihood of the more general model. A $\chi^{2}$ with 1 degree of freedom was used to test the significance of $D$ for each effect.

Genetic parameters and breeding values

Individual, narrow-sense heritabilities were estimated as $4 \times \sigma_{\text {Fam(Prov) }}^{2} / \sigma_{P}^{2}$, where $\sigma_{\text {Fam(Prov) }}^{2}$ was the variance of the family-within-provenance effect and $\sigma^{2}{ }_{P}$ is the phenotypic variance, a sum of the variances due to the provenance, family-within-provenance and error. Across sites, additional variances added to $\sigma^{2}{ }_{p}$ were; site $\times$ provenance and site $\times$ family-within-provenance.

Genetic correlations were estimated as the correlation of the family-within-provenance effect between sites, and fixing the error co-variance between sites, to zero.

Across-site breeding values were estimated using model [2] and the three key trials: Kaingaroa, Golden Downs and Gowan Hill. Manuka Awa was excluded from breeding value estimation as the site was considered atypical for deployment.

\section{Genotype $\times$ Environment interaction}

Genotype $\times$ environment interaction was investigated through the following methods (MATHESON and RAYMOND, 1984):

1. The estimation of type B genetic correlations (same trait, between sites) in ASReml (BURDON, 1977).

2. Analysis of variance, to test for the significance of the interaction term [site $\times$ provenance and site $\times$ family within provenance].

3. Comparison of variance components. SHELBOURNE (1972) indicated that as a 'rule of thumb', where the interaction term exceeds $50 \%$ or more than the family [or provenance] component, then the effects of the genotype $\mathrm{x}$ environment interaction are likely to be important for gains, selection and testing.

\section{Genetic gains}

Genetic gains were predicted from the breeding values estimated, as a percentage improvement over control seedlots:

1. The top 20 selections at each site and across sites;

2. The top 100 selections (reasonable for a breeding population).

Table 4. - Age at which traits were assessed for each site.

\begin{tabular}{|l|l|c|c|c|c|}
\hline Trait & Description & \multicolumn{3}{|c|}{ Site } \\
\hline & \multicolumn{1}{|c|}{$\begin{array}{c}\text { Manuka } \\
\text { Awa }\end{array}$} & Kaingaroa & $\begin{array}{c}\text { Golden } \\
\text { Downs }\end{array}$ & $\begin{array}{c}\text { Gowan } \\
\text { Hill }\end{array}$ \\
\hline DBH & Diameter at breast height (1.4m) & 9 & 11 & 13 & 11 \\
\hline Straightness & $\begin{array}{l}1-9 \text { scale, where 1,2,3,4 are unacceptable, } \\
6,7,8,9 \text { are good }\end{array}$ & 11 & 13 & 11 \\
\hline MAL & $\begin{array}{l}\text { Malformation score, 1-9 where 9 = no forks or } \\
\text { ramicorns and 1 = multiple forking or leaderless } \\
\text { bush }\end{array}$ & & 11 & 13 & 11 \\
\hline $\begin{array}{l}\text { Needle } \\
\text { retention/NR }\end{array}$ & $\begin{array}{l}\text { Each 6 months of needles scores 1 point, with a } \\
\text { maximum of 6, Kaingaroa only. This is a measure } \\
\text { of Swiss needle cast tolerance. }\end{array}$ & & 7 & & \\
\hline VEL & $\begin{array}{l}\text { Acoustic velocity, a surrogate for wood stiffness } \\
\text { measured by the IML/ST300* }\end{array}$ & & 12 & 13 & 11 \\
\hline
\end{tabular}

*(Anonymous, 2001), the Hitman ST300 was used to measure Golden Downs, and Kaingaroa; the IML Hammer was used at Gowan Hill. 
Control seedlots were separated for interest, as some were from different provenance origins, but then combined in an overall average 'control' comparison.

Implications on genotype selection using breeding values from all sites compared with selection at individual sites were investigated by comparing the genetic gain achieved for each trait [DBH and STR]. Genetic gains were estimated for VEL and needle retention selections in comparison with the population mean across sites, as control seedlots were not measured for VEL in this trial series. A genetic gain for needle retention was only estimated at Kaingaroa.

\section{Results}

\section{Site, provenance and family effects}

Across sites, all effects in the model were significant for DBH STR and MAL $(\mathrm{P}<0.03$; Table 5). The trait VEL was not significant for the provenance, site $\times$ provenance and site $\times$ family-within-provenance effect for VEL. These results indicate no geno type $\times$ environment interaction for VEL, but a significant interaction for the traits DBH STR and MAL.

At individual sites, the provenance and family within provenance effect was significant for the majority of

Table 5. - Across-site individual narrow-sense heritabilities $\left(\mathrm{h}^{2}\right)$, multi-site variance components (Var) and their standard errors (SE) for DBH (ages 9 to 13), straightness (ages 11 to 13), malformation (ages 11 to 13) and acoustic velocity (ages 11 to 13).

\begin{tabular}{|l|c|c|c|c|c|c|c|c|c|c|c|c|}
\hline & \multicolumn{3}{|c}{ Diameter } & \multicolumn{3}{c|}{ Straightness } & \multicolumn{3}{c|}{ Malformation } & \multicolumn{2}{c|}{ Acoustic Velocity } \\
\hline & Var & SE & Sig & Var & SE & Sig & Var & SE & Sig & Var & SE & Sig \\
\hline Provenance & 164.4 & 55.10 & $* * *$ & 0.039 & 0.024 & n.s. & 0.0372 & 0.0205 & $*$ & 0.0000 & 0.0000 & n.s. \\
\hline Replicate(site) & 48.92 & 8.207 & $* * *$ & 0.171 & 0.028 & $* * *$ & 0.6208 & 0.0982 & $* * *$ & 0.0030 & 0.0001 & $* * *$ \\
\hline Family(provenance) & 54.27 & 7.418 & $* * *$ & 0.1361 & 0.018 & $* * *$ & 0.0491 & 0.0136 & $* * *$ & 0.0093 & 0.0023 & $* \star *$ \\
\hline Site*provenance & 66.00 & 15.95 & $* \star *$ & 0.0415 & 0.0127 & $\star * *$ & 0.0391 & 0.0142 & $* * *$ & 0.0005 & 0.0009 & n.s. \\
\hline Site*family(provenance) & 18.34 & 4.136 & $* * *$ & 0.0294 & 0.0094 & $* * *$ & 0.0336 & 0.0159 & n.s. & 0.0017 & 0.0017 & n.s. \\
\hline Error & 975.7 & 10.57 & & 2.500 & 0.0272 & & 4.703 & 0.0512 & & 0.0642 & 0.0025 & \\
\hline Phenotypic variance & 1279 & 56.69 & & 2.747 & 0.0394 & & 4.862 & 0.0556 & & 0.0757 & 0.0031 & \\
\hline Additive variance & 217.1 & 29.67 & & 0.5444 & 0.0722 & & 0.1963 & 0.0542 & & 0.0372 & 0.0090 & \\
\hline $\mathbf{h}^{2}$ & $\mathbf{0 . 1 7}$ & $\mathbf{0 . 0 2}$ & & $\mathbf{0 . 2 0}$ & $\mathbf{0 . 0 3}$ & & $\mathbf{0 . 0 4}$ & $\mathbf{0 . 0 1}$ & & $\mathbf{0 . 4 9}$ & $\mathbf{0 . 1 1}$ & \\
\hline
\end{tabular}

Significances of each of the variance components are given $(\mathrm{Sig})$ where ${ }^{* * *} \mathrm{P}<0.001,{ }^{*} 0.05>\mathrm{P}>0.01$, n.s. $=$ not significant i.e. $\mathrm{P}>0.05$.

Table 6. - Individual-site individual narrow-sense heritabilities $\left(\mathrm{h}^{2}\right)$, variance components (Var) and their standard errors (SE) for DBH (ages 9 to 13), straightness (ages 11 to 13), malformation (ages 11 to 13), acoustic velocity (ages 11 to 13) and needle retention (age 7).

\begin{tabular}{|c|c|c|c|c|c|c|c|c|c|c|}
\hline \multirow[t]{2}{*}{ Site/Source } & \multicolumn{2}{|c|}{ Diameter } & \multicolumn{2}{|c|}{ Straightness } & \multicolumn{2}{|c|}{ Malformation } & \multicolumn{2}{|c|}{ Acoustic velocity } & \multicolumn{2}{|c|}{ Needle retention } \\
\hline & Var & SE & Var & SE & Var & SE & Var & SE & Var & SE \\
\hline \multicolumn{11}{|l|}{ Kaingaroa } \\
\hline Provenance & 311.91 & 95.55 & 0.040 & 0.019 & 0.091 & 0.038 & 0.000 & 0.000 & 0.030 & 0.014 \\
\hline Replicate & 47.591 & 14.26 & 0.042 & 0.014 & 0.065 & 0.025 & 0.002 & 0.002 & 0.031 & 0.012 \\
\hline Family(provenance) & 100.64 & 15.35 & 0.110 & 0.021 & 0.062 & 0.029 & 0.023 & 0.006 & 0.072 & 0.013 \\
\hline Error & 1124.2 & 21.85 & 2.246 & 0.044 & 5.350 & 0.104 & 0.098 & 0.006 & 0.721 & 0.019 \\
\hline Phenotypic variance & 1224.8 & 25.91 & 2.356 & 0.047 & 5.412 & 0.104 & 0.121 & 0.008 & 0.793 & 0.022 \\
\hline Additive variance & 402.55 & 67.41 & 0.440 & 0.084 & 0.250 & 0.118 & 0.090 & 0.024 & 0.288 & 0.053 \\
\hline $\mathrm{h}^{2}$ & 0.33 & 0.05 & 0.19 & 0.03 & 0.05 & 0.02 & 0.75 & 0.17 & 0.36 & 0.06 \\
\hline \multicolumn{11}{|l|}{ Golden Downs } \\
\hline Provenance & 216.6 & 65.37 & 0.022 & 0.015 & 0.029 & 0.014 & 0.001 & 0.002 & & \\
\hline Replicate & 51.691 & 14.87 & 0.059 & 0.019 & 0.079 & 0.025 & 0.003 & 0.002 & & \\
\hline Family(provenance) & 71.033 & 10.95 & 0.166 & 0.026 & 0.020 & 0.014 & 0.009 & 0.004 & & \\
\hline Error & 973.79 & 18.11 & 2.405 & 0.045 & 3.280 & 0.061 & 0.074 & 0.005 & & \\
\hline Phenotypic variance & 1044.8 & 20.53 & 2.571 & 0.050 & 3.300 & 0.060 & 0.083 & 0.006 & & \\
\hline Additive variance & 284.13 & 43.80 & 0.663 & 0.102 & 0.079 & 0.058 & 0.035 & 0.014 & & \\
\hline $\mathrm{h}^{2}$ & 0.27 & 0.04 & 0.26 & 0.04 & 0.02 & 0.02 & 0.42 & 0.16 & & \\
\hline \multicolumn{11}{|l|}{ Gowan Hill } \\
\hline Provenance & 148.11 & 50.02 & 0.144 & 0.058 & 0.112 & 0.051 & 0.001 & 0.001 & & \\
\hline Replicate & 46.757 & 13.40 & 0.412 & 0.112 & 1.727 & 0.462 & 0.003 & 0.001 & & \\
\hline Family(provenance) & 53.354 & 8.74 & 0.225 & 0.034 & 0.174 & 0.040 & 0.002 & 0.001 & & \\
\hline Error & 845.98 & 15.49 & 2.823 & 0.052 & 5.530 & 0.103 & 0.024 & 0.002 & & \\
\hline Phenotypic variance & 899.33 & 17.24 & 3.048 & 0.061 & 5.705 & 0.106 & 0.026 & 0.002 & & \\
\hline Additive variance & 213.42 & 34.94 & 0.901 & 0.136 & 0.698 & 0.160 & 0.009 & 0.004 & & \\
\hline $\mathrm{h}^{2}$ & 0.24 & 0.04 & 0.30 & 0.04 & 0.12 & 0.03 & 0.34 & 0.15 & & \\
\hline \multicolumn{11}{|l|}{ Manuka Awa } \\
\hline Provenance & 51.42 & 21.69 & & & & & & & & \\
\hline Replicate(site) & 20.28 & 15.43 & & & & & & & & \\
\hline Family(provenance) & 28.90 & 9.90 & & & & & & & & \\
\hline Rep*family(provenance) & 18.27 & 12.04 & & & & & & & & \\
\hline Error & 517.03 & 19.34 & & & & & & & & \\
\hline Phenotypic variance & 564.20 & 19.28 & & & & & & & & \\
\hline Additive variance & 115.61 & 39.58 & & & & & & & & \\
\hline $\mathrm{h}^{2}$ & 0.20 & 0.07 & & & & & & & & \\
\hline
\end{tabular}



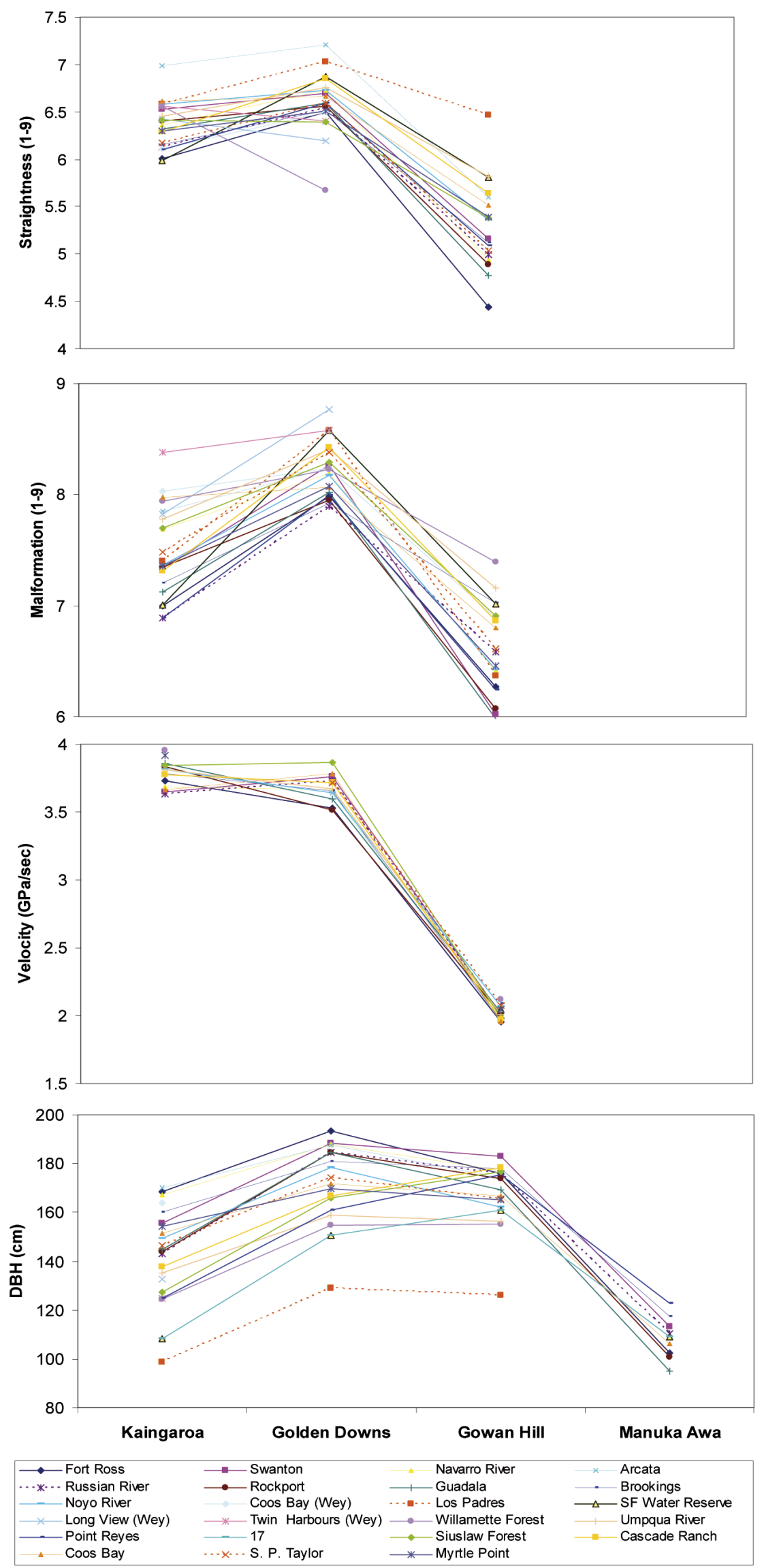

Figure 2. - Provenance least-squares means for DBH, MAL, STR and VEL across all sites. Note different tools were used at different sites for VEL, so this acrosssite comparison is confounded with tool type. (the IML Hammer was used at Gowan Hill , the Hitman ST300 tool was used at Kaingaroa and Golden Downs). 
traits (Table 6), except VEL ( $\mathrm{P}<0.05$; data not shown). Family within provenance was not significant for malformation at age 13 from planting at Golden Downs $(\mathrm{P}=0.1)$. Provenance effects for VEL were not significant at any of the three sites where this was measured (Kaingaroa, Golden Downs and Gowan Hill). Needle retention (NR), had highly significant provenance and familywithin-provenance effects at Kaingaroa.

Ratios of provenance $\times$ site: provenance variances for DBH were less than $50 \%(40 \%)$, whereas the ratios for STR, VEL and MAL were all above 50\% (106, 83000 and $105 \%$ respectively). Similar ratios for family: family $\mathrm{x}$ site variances were determined to be all below $50 \%$ for DBH, STR and VEL (34, 22 and $18 \%$ respectively), but important and above $50 \%$ for MAL (68\%).

\section{Provenance means}

Provenance means across sites were definitely more variable for $\mathrm{DBH}$ than for any of the other traits across sites (Figure 2), particularly between Kaingaroa and Manuka Awa and Kaingaroa and Gowan Hill. The Los Padres provenance consistently had the smallest DBH, however, the top provenances were usually the top provenances across sites. In spite of there being significant provenance $\mathrm{x}$ site interactions for straightness
(Table 5), provenance means for straightness were reasonably consistent across sites. A few 'reactive' provenances were noted (e.g., Willamette Forest between Golden Downs and Kaingaroa), but relative to $\mathrm{DBH}$ there were few interactions. Mean provenance VEL was also remarkably consistent across sites (Figure 2), although there appeared to be a few reactive provenances at the Golden Downs and Kaingaroa sites. For MAL, there appeared to be some interaction between Kaingaroa and Golden Downs, but mean provenance MAL was relatively consistent between Golden Downs and Gowan Hill (Figure 2).

\section{Heritabilities}

Heritabilities were estimated from the variance component estimates in Table 5. The overall across-sites heritiablity for MAL was very low (0.04). DBH and STR heritability estimates were in the typical range for these traits of low-to-moderate ( 0.17 , and 0.20 , respectively), and for VEL moderate-to-high (0.49). The heritability for NRA, again estimated only at Kaingaroa, and was moderate (0.37).

Heritabilities at individual sites were reasonably consistent for DBH (0.2-0.33), somewhat low for STR at Kaingaroa (0.19) and consistently low for MAL

Table 7. - Predicted genetic gains (\%) estimated from selection of the top 20 and top 100 families when compared with the control seedlots of different origin (Fort Bragg, Washington, Oregon and Arcata), and when averaged across all control seedlots.

\begin{tabular}{|c|c|c|c|c|c|c|c|}
\hline & & \multicolumn{2}{|c|}{ DBH } & \multicolumn{2}{|c|}{ STR } & \multicolumn{2}{|c|}{ NR } \\
\hline & $\begin{array}{l}\text { Control } \\
\text { Code No. }\end{array}$ & $\begin{array}{c}\text { Top } \\
20\end{array}$ & $\begin{array}{l}\text { Top } \\
100\end{array}$ & $\begin{array}{c}\text { Top } \\
20\end{array}$ & $\begin{array}{l}\text { Top } \\
100\end{array}$ & $\begin{array}{c}\text { Top } \\
20\end{array}$ & $\begin{array}{l}\text { Top } \\
100\end{array}$ \\
\hline \multicolumn{8}{|l|}{ Kaingaroa } \\
\hline $\begin{array}{l}\text { Fort Bragg, } \\
\text { CA }\end{array}$ & $\begin{array}{l}900,901, \\
903\end{array}$ & -0.11 & -8.99 & 8.86 & 4.34 & 0.77 & -6.81 \\
\hline Washington & 902,906 & 21.59 & 10.78 & 9.15 & 4.61 & 9.51 & 1.27 \\
\hline Oregon & 904,905 & 20.16 & 9.48 & 12.70 & 8.02 & 11.42 & 3.05 \\
\hline Arcata & 907 & 11.29 & 1.40 & 4.01 & -0.32 & 17.33 & 8.51 \\
\hline OVERALL & & 12.54 & 2.53 & 8.59 & 4.07 & 9.43 & 1.20 \\
\hline \multicolumn{8}{|c|}{ Golden Downs } \\
\hline $\begin{array}{l}\text { Fort Bragg, } \\
\text { CA }\end{array}$ & $\begin{array}{l}900,901, \\
903\end{array}$ & 2.71 & -2.25 & 11.54 & 6.94 & & \\
\hline Washington & 902,906 & 15.64 & 10.05 & 10.39 & 5.84 & & \\
\hline Oregon & 904,905 & 23.93 & 17.94 & 14.01 & 9.30 & & \\
\hline Arcata & 907 & 14.17 & 8.65 & -0.65 & -4.75 & & \\
\hline OVERALL & & 13.60 & 8.11 & 8.52 & 4.04 & & \\
\hline \multicolumn{8}{|l|}{ Gowan Hill } \\
\hline $\begin{array}{l}\text { Fort Bragg, } \\
\text { CA }\end{array}$ & $\begin{array}{l}900,901, \\
903\end{array}$ & 8.08 & 3.37 & 29.85 & 21.40 & & \\
\hline Washington & 902,906 & 16.32 & 11.25 & 20.02 & 12.22 & & \\
\hline Oregon & 904,905 & 10.39 & 5.58 & 30.38 & 21.90 & & \\
\hline Arcata & 907 & 5.49 & 0.89 & 11.55 & 4.29 & & \\
\hline OVERALL & & 9.93 & 5.14 & 22.44 & 14.48 & & \\
\hline \multicolumn{8}{|l|}{ Across sites } \\
\hline $\begin{array}{l}\text { Fort Bragg, } \\
\text { CA }\end{array}$ & $\begin{array}{l}900,901, \\
903\end{array}$ & 1.41 & -3.93 & 13.83 & 8.85 & & \\
\hline Washington & 902,906 & 14.21 & 8.19 & 13.45 & 8.49 & & \\
\hline Oregon & 904,905 & 18.80 & 12.55 & 18.69 & 13.50 & & \\
\hline Arcata & 907 & 9.98 & 4.19 & 1.75 & -2.70 & & \\
\hline OVERALL & & 10.72 & 4.89 & 11.57 & 6.68 & & \\
\hline
\end{tabular}


(0.02-0.12; Table 6). Heritability for VEL was high at Kaingaroa (0.75), and moderate for the other two sites (0.34 and 0.42).

\section{Genetic gains}

Over the three main sites, gains for $\mathrm{DBH}$ were estimated as $4.9 \%$ (top 100) and $10.7 \%$ (top 20; Table 7). As expected, genetic gains when selecting for $\mathrm{DBH}$ were highest when estimated against the control material from Washington or Oregon origin. The greatest gains for $\mathrm{DBH}$ estimated across all control seedlots were from the top 20, at Golden Downs. Fort Bragg control seedlots at Kaingaroa were actually superior to the top 20 and top 100 comparisons, indicating that Fort Bragg is a very fast-growing provenance at this site. In comparison, at Gowan Hill, gains estimated against the Fort Bragg seedlots were reasonable ( $8 \%$ top 20 ). The growth of the Fort Bragg seedlots was therefore a lot slower at Gowan Hill when compared with the selections at Kaingaroa.

Over the three main sites, gains for stem straightness (STR) were estimated as $6.7 \%$ (top 100) and $11.6 \%$ (top 20; Table 7). Gains ranged between -4.75 (Top 100, with Arcata as the benchmark control at Golden Downs) to $32 \%$ (Top 10, with Oregon as the benchmark control at Gowan Hill). The Arcata control seedlot compared well with the straightest selections, particulary at Golden Downs, where only the top 10 selections were $1.18 \%$ straighter than this seedlot. Similarly, the Oregon seedlots appeared to have some of the worst trees for straightness amongst the controls, particularly at Gowan Hill. At this site Fort Bragg also suffered from trees that were not straight compared with the top selections.

Genetic gains for VEL were estimated, as for the other traits benchmarked against the population mean, for the top 20 and 100 selections as 6.96 and $1.30 \%$ respectively. An improvement of $32.5 \%$ in needle retention for the top 20 families was estimated compared with the site average.

We also compared gains for the top 20 families based on NRA from Kaingaroa, and the effect this had on the overall gains for DBH. Similarly, we compared gains for DBH if we selected only on breeding values from Kaingaroa versus across-site breeding values, and the effect this would have on gains for NRA. When we compared gains for the top 20 families, based on individual-trait selection of NRA or DBH at Kaingaroa, the predicted improvement was $9.4 \%$ for NRA and $12.5 \%$ for $\mathrm{DBH}$. When we only selected for NRA alone, gains for acrosssite $\mathrm{DBH}$ dropped dramatically to $1.2 \%$. When we selected for $\mathrm{DBH}$ across sites alone, gains for NRA at Kaingaroa fell to $-4.8 \%$. When selecting for NRA at Kaingaroa, the DBH gain at Kaingaroa (12.5\%), was greater than the gain expected for $\mathrm{DBH}$ across sites $(10.7 \%)$.

All gains were then estimated compared with the average of all control seedlots. The first thing to note was that gains made from selection of outstanding families at Gowan Hill were different from those that would be made using across-site breeding values (Figure $3 a$ and $b$, selected families indicated by open circles). Some gain would be reduced from selection at Gowan Hill, using across-site breeding values for both traits. The second thing to note was that individual-trait gain for NRA was small in both scenarios $(1.4 \%$ Gowan Hill, $0.9 \%$ across sites). The same was true for $\mathrm{DBH}(5.6 \%$ Gowan Hill, 7.9\% across sites). Needle retention, however, made virtually no gain in the across-site selection scenario. Hence to make significant gain, this exercise has confirmed the need to concentrate on selection in SNC-prone areas.

\section{Across-site correlations}

Provenance-mean correlations were moderate for DBH (0.55-0.77, Table 8). The highest correlation was
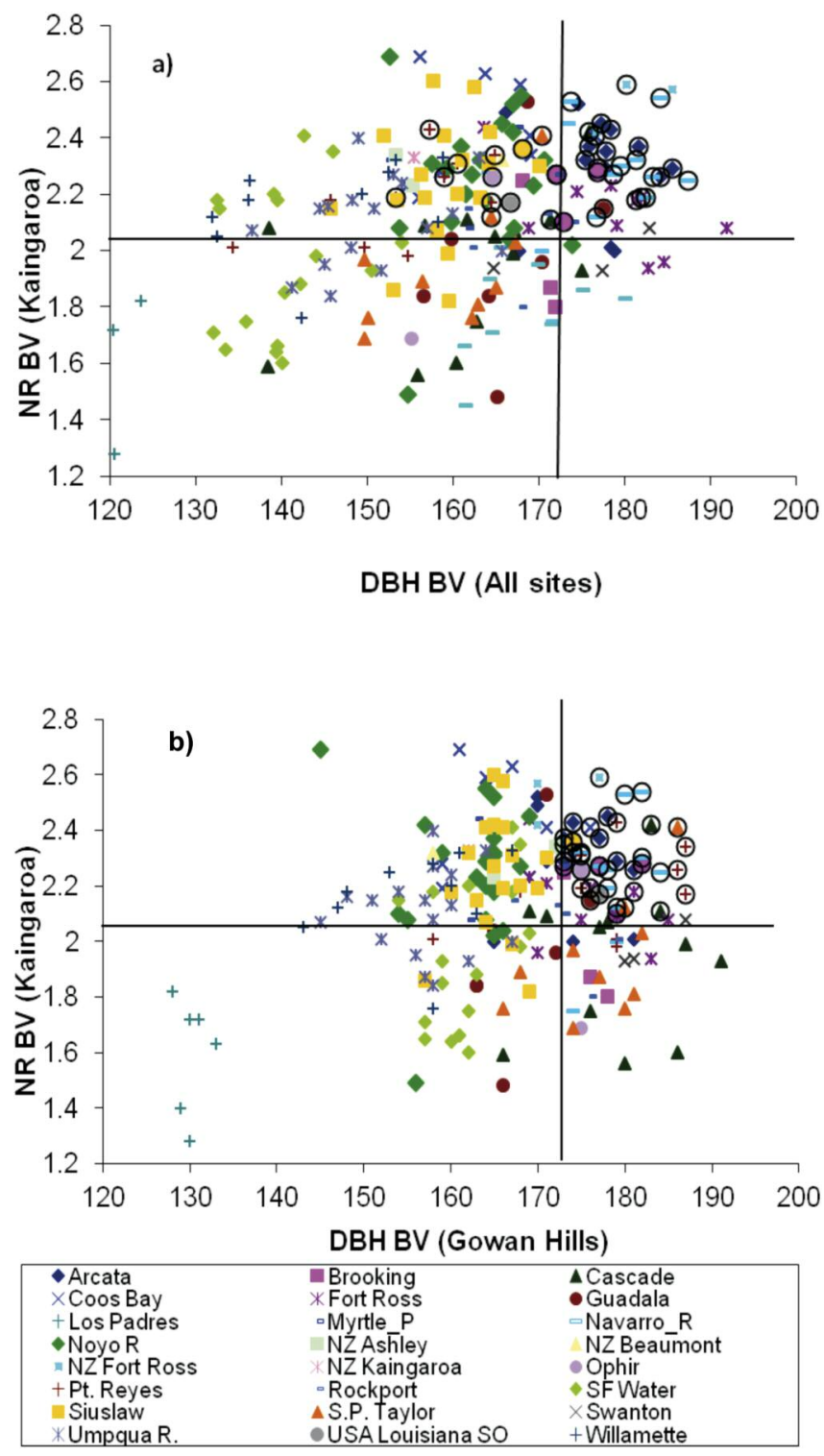

Figure 3. - Family-within-provenance breeding values for NR (tolerance to Swiss needle cast) estimated at Kaingaroa and compared with a) DBH breeding values estimated from across all sites and b) DBH breeding values from Gowan Hill (independent from needle cast). The top twenty selections using across-site DBH breeding values (a, open circles) are compared with the same families using breeding values from only Gowan Hill (b, open circles). 
Table 8. - Genetic correlations estimated across sites for the same trait (type-B genetic correlations) for the provenance effect.

\begin{tabular}{|l|l|l|l|l|}
\hline & & Kaingaroa & Golden Downs & Gowan Hill \\
\hline DBH (9-13 years) & Golden Downs & $0.77 \pm 0.15$ & & \\
\hline & Gowan Hill & $0.55 \pm 0.17$ & $0.76 \pm 0.11$ & \\
\hline & Manuka Awa & $0.63 \pm 0.14$ & $0.64 \pm 0.14$ & $0.69 \pm 0.18$ \\
\hline & & & & \\
\hline STR (11-13 years) & Golden Downs & $0.49 \pm 0.31$ & & \\
\hline & Gowan Hill & $0.43 \pm 0.26$ & $0.67 \pm 0.22$ & \\
\hline
\end{tabular}

Table 9. - Genetic correlations estimated across sites for the same trait (type-B genetic correlations) for families-within-provenances.

\begin{tabular}{|l|l|l|l|l|}
\hline & & Kaingaroa & Golden Downs & Gowan Hill \\
\hline DBH (9-13 years) & Golden Downs & $0.75 \pm 0.09$ & & \\
\hline & Gowan Hill & $0.61 \pm 0.08$ & $0.72 \pm 0.08$ & \\
\hline & Manuka Awa & $0.68 \pm 0.14$ & $0.69 \pm 0.15$ & $0.73 \pm 0.18$ \\
\hline & & & & \\
\hline STR (11-13 years) & Golden Downs & $0.91 \pm 0.08$ & & \\
& Gowan Hill & $0.82 \pm 0.08$ & $0.85 \pm 0.07$ & \\
\hline & & & & \\
\hline VEL (11-13 years) & Golden Downs & NE & & \\
\hline & Gowan Hill & $0.97 \pm 0.30$ & NE & \\
\hline
\end{tabular}

$\mathrm{NE}=$ reliable estimates were not able to be calculated.

between Kaingaroa and Golden Downs (0.77), which was surprisingly higher than the two closest sites Manuka Awa and Gowan Hill (0.69). Correlations between Kaingaroa and the two southernmost sites Gowan Hill and Manuka Awa were the lowest but still moderate ( 0.55 and 0.63 respectively). It was interesting to note that Golden Downs and Gowan Hill were also reasonably well correlated (0.76). Provenance straightness was not well correlated between Kaingaroa and the South Island sites (0.43-0.49, Table 8), whereas between the two South Island sites provenances were moderately correlated (0.67).

Genetic correlations were estimated for families-within-provenances among the three main trial sites (Table 9). Correlations were moderate-to-high for most traits, VEL (when estimable) and STR were the highest, indicating the most consistent performance of families-within-provenances across sites. Correlations for $\mathrm{DBH}$ were highest between Kaingaroa and Golden Downs, and moderate-to-high between the other site combinations (0.61-0.72). The lowest genetic correlations for $\mathrm{DBH}$ were between the North Island Kaingaroa site and the two southern South Island sites - Gowan Hill and Manuka Awa (0.61 and 0.68 respectively). Straightness was highly correlated across sites for families within provenances (0.82-0.91, Table 9). Similar to DBH, STR was more highly correlated between Kaingaroa and Golden Downs (0.91) than with the Gowan Hill (0.82), and more so than between Golden Downs and Gowan Hill (0.85).

Overall, correlations at the family-within-provenance level were stronger than at the provenance level between sites. Estimates for provenance for VEL were not able to be obtained, as there was not enough materi- al in common across sites for this trait, making it impossible to estimate reliable correlations.

\section{Discussion \\ $G \times E$ and SNC Resistance}

There appears to be some genotype $\times$ environment interaction among provenances for $\mathrm{DBH}$ but this interaction is much less important at the family level. While it could be argued, based on the (SHELBouRne, 1972) 'rule of thumb' for variance components that genotype $\times$ environment interaction is important, it is not important for family means for the majority of traits. Straightness and VEL were relatively consistent across sites, and while there was some change in MAL across sites, it is likely to be caused by the higher winds prevalent on the most southern sites. The large ratio of variance components for VEL was likely to be due a small and imbalanced number of provenances that were sampled, giving poor variance component estimates.

Other genotype $\times$ environment studies have indicated that rank changes among sites (growth) were not large enough to be an operational issue for coastal Douglas-fir in western Washington, USA (DEAN, 2007). Female parent within a population $\mathrm{x}$ test (within an environment) was the largest effect noted, explaining $2 \%$ of the variation for $\mathrm{DBH}$ at age 13 . There was virtually no variation for the effect of female parent within a population $\mathrm{x}$ region (DEAN, 2008). It was the population of the pollen, or origin of the pollen parent that interacted with environment, explaining $0.4 \%$ of the variation for $\mathrm{DBH}$ at age 21 , all other interactions at the broad scale were not significant (female population $\mathrm{x}$ region, female population $\mathrm{x}$ test within region) (DEAN, 2009). Within 
populations, the female parent $\mathrm{x}$ test (within a region) was significant, at $2 \%$ of the total variation. Clonal performance across Oregon and Washington were also found to be highly stable, through genetic correlations between environments of $0.84 \pm 0.04$, and variance between clones four times greater than the variance of the clone $\mathrm{x}$ environment interaction (DEAN, 2008). It appears that there is general evidence for some genotype $\mathrm{x}$ environment interaction at the level of populations (or provenances), and very little interaction at the level of families-within-provenance.

Genotype $\mathrm{x}$ environment interaction in Douglas-fir trials in Canada has been observed to be significant in some instances and insignificant in others (KRAKOWSKI and Stoenr, 2009; White and CHING, 1985; CHING and HINZ, 1978) with differences observed largely consistent over time (KRAKOWSKI and STOEHR, 2009). While the existence of genotype $\mathrm{x}$ environment interaction in some trials and not in others have been attributed to differences in test sites and the provenance composition of the test themselves, the best provenances were always the best provenance and the worst were always the worst (KRAKOWSKI and STOEHR, 2009).

Research in Oregon, however, has determined that risk of maladaptation increases with the size of the environmental gradients under examination (ADAMS and CAMPBELL, 1981), and moving populations east-west is generally riskier than north-south within the species' natural distribution (CAMPBELL and SORENSEN, 1978). Allozyme and microsattelite markers used to study the population structure of coastal Douglas-fir have shown that there is weak differentiation between the coastal populations (KRUTOVsKY et al., 2009). Had the trials examined here been established on harsher sites in New Zealand, particularly with a lot of wind exposure or where rainfall is more limited, it is possible that the genotype $\mathrm{x}$ environment interaction found would have increased. The evidence of low differentiation from KRUTOVSKY et al. (2009) suggests that there may not be value in doing so. It would, however, be productive to integrate data from these studies in New Zealand with those from (DEAN, 2007; DEAN, 2008; DEAN, 2009) or similar studies, to determine whether similar levels of provenance $\mathrm{x}$ environment effects exist. However, as discussed next, the presence and impact of SNC in some regions of New Zealand provides an added complication.

Needle cast from SNC was found to be moderately heritable at Kaingaroa, indicating that selection for this trait would yield improvements in tolerance to this disease. This compares with heritability estimates in the literature for crown density of $0.16-0.44$ and for needle retention of 0.03-0.34 (JoHNSON, 2002). Different field and laboratory studies have yielded a range of heritability estimates; individual and family heritabilities of $0.15-0.23$ for needle colour $(0.15,0.49)$, foliage colour $(0.15,0.50)$, needle retention $(0.23,0.60)$, and foliage density $(0.25,0.64)$ in Oregon, USA (TEMEL et al., 2005). Assessments for needle retention were consistently amongst those yielding the higher heritability estimates in these studies. The current method for assessing damage caused by SNC in New Zealand is a subjective scale for needle retention that is rapid and allows screening of large populations, such as those in genetics trials. It also appears that it is tolerance to SNC, rather than resistance to the pathogen that is important (TEMEL et al., 2005; TEMEL et al., 2004). Therefore, using the current assessment method to estimate the extent of needle retention is likely to be highly effective.

Currently, SNC mostly affects plantations in the North Island, with the cooler temperatures in the South Island reducing both the incidence and severity of the disease (STONE et al., 2007). While incidence and damage can be reduced with early thinning as well as planting on higher-altitude sites, this is not feasible in most areas of in the North Island that typically have higher levels of infection.

Here we detected a significantly lower genetic correlation between Kaingaroa and Gowan Hill, which indicated that there does appear to be some potentially important rank changes between sites with $\mathrm{SNC}$, and/or with different growing conditions; however, we expect this is driven largely by changes in rankings due to differing tolerances to SNC on the North Island site. We examined the impact on potential gains by selection of outstanding individuals for growth, when selection was done in the population largely free of SNC, and then, when selection was undertaken using breeding values across all trials, not independent of SNC (Figure 3). The impact was quite obvious (Figure 3). If genotypes were selected using data without the presence of the disease, significant loss in NR was predicted for sites where SNC tolerance or resistance is required.

With the possibility that climate change will increase the occurance and severity of SNC on the coastal South Island (WATT et al., 2010), the impact of this disease on future breeding and deployment becomes even more important. Volume losses of up to $50 \%$ are possible, particularly in the warmer, milder coastal areas (WATT et al., 2010). Similar work in Oregon has determined that top height growth of infected forests was reduced by up to $25 \%$. In setting up the next generation of Douglas-fir, selections tolerant to SNC are needed. The heritability of needle retention estimated here at Kaingaroa (0.37) indicates that selection and breeding for needle retention would be quite effective.

\section{Breeding and Deployment of Douglas-fir in New Zealand}

Douglas-fir breeding strategy in New Zealand follows an adapted strategy as described by (SHELBOURNE et al., 2007), where three superlines remain, defined basically as (i) the early range-wide collections (1959 trials), (ii) the California and Oregon collections (1996 trials) and (iii) some New Zealand landrace selections. Eventually, the aim is to merge all super-lines to maximise gain (Dungey et al. unpublished report), however, there was no separation of breeding or deployment areas for the breeding programme.

Up to the present, the deployment of Douglas-fir material has primarily been from seed stands and a small amount from privately owned seed orchards, which have only just started producing commercial amounts of seed. There is a substantial body of industry 
experience of what New Zealand land race seed sources to plant where, and in this sense there has been regional deployment, e.g. seed of Washington origin is often planted in Southland. Here we have identified potentially new seed orchard material, for each key regions along the same lines: perhaps aligned into three areas, in the south and north of the South Island (Southland and Nelson areas) and the Central North Island.

In order to plan for the next rotation, these areas will need to be demarked for deployment. We propose that, while the breeding strategy remains the same, that selections for deployment are made for two distinct areas - firstly, the North Island as well as the top of the South Island (North), and Southland/Otago (South). Testing the next generation will require trials in all these areas, with a minimum of three trials, perhaps four, to enable some local selection.

For more immediate deployment, we propose initially to identify females within seed orchards that have performed well in the South, and to deploy seed from these females in the South. Conversely, we propose that seed from females that have performed well in the North, largely based on SNC tolerance, will be deployed in the North. In addition, as the Douglas-fir seed orchards were initially intended as 'rolling front' orchards, where new selections are regularly added, and old selections culled (SHELBOURNE et al., 2007), we propose that with new selections, all North selections will be added to one seed orchard, and all South selections to the other. In time, this will give seed orchards for each of the key areas without disadvantaging the owners of the seed orchards or the success of Douglas-fir deployment. All selections in the North seed orchard will need to be selected not only for growth, form and wood stiffness, but for tolerance to SNC.

\section{Conclusions}

There are some genotype $\times$ environmental interactions between the South Island and North Island sites for DBH in New Zealand, probably due to a combination of tolerance to SNC and adaptive traits. This disease will need to be considered in making selections for deployment over the next $40-50$ years. VEL appears to not have an important genotype $\times$ environment interaction but more work is needed to verify this. Gains estimated for family-within-provenance selection across sites are very reasonable for growth, straightness, velocity and needle retention.

We propose that for future breeding that the North Island and the top of the South Island are treated as a separate deployment areas. Separate seed orchards will be needed to provide seed for the southern South Island and the north of the South Island and the North Island. It will be very important to ensure all breeding trials with SNC symptoms are assessed for needle retention. Archiving the top selections will not only give breeders and forest managers who want to utilize Douglas-fir the flexibility to respond to an increase in this disease. These approaches will help build resilient forests for New Zealand's future.

\section{Acknowledgements}

Thanks to Nelson Forests for hosting the Golden Downs trial, to Rayonier for hosting the Manuka Awa site, to Timberlands for hosting the Kaingaroa site and to Ernslaw One for hosting the Gowan Hill trial site. Thanks to the whole team at Scion, including ToBY Stovold, Mark Miller, Kane Fleet, David Henley, ROWLAND BURDON and ViCKY HODDER. Thanks also to Luigi Gea. Figure 1 and climate data in Table 3 were provided by MARIE HEAPHY and DAVID PALMER.

Any recent Douglas-fir research in New Zealand must acknowledge the determination of the late Leith Knowles, who managed to catapult the Douglas-fir Cooperative to the vibrant group of growers and consultants it became prior to merging with FFR. Thanks Leith.

This publication was funded by Future Forests Research, Diversified Species Theme, via FRST contract CO4X0805: Diverse Forests and by Scion.

\section{References}

ADAMS, T. and R. K. CAMPBELL (1981): Genetic adaptation and seed source specificity. Reforestation of skeletal soils. Proc. workshop, November 1981, Medford, Oregon: 78-85.

BuRDON, R. D. (1977): Genetic correlation as a concept for studying genotype-environment interaction in forest tree breeding. Silvae Genetica 26: 168-175.

CAMPBell, R. K. and F. C. Sorensen (1978): Effect of test environment on expression of clines and on delimitation of seed zones in Douglas-fir. Theoretical and Applied Genetics 51: 233-246.

Ching, K. K. and P. N. Hinz (1978): Provenance study of Douglas-fir in the Pacific Northwest region. III. Field performance at age twenty years. Silvae Genetica 27: 229-233.

Cown, D. J. (1976): Densitometric studies of wood of young coastal Douglas-fir (Pseudotsuga menziesii (Mirb. (Franco.)), 241 pp. University of British Columbia; Victoria, Canada.

Cudmore, T. J., N. BJörklund, A. L. CARroll and B. STAFFAN LINDGREN (2010): Climate change and range expansion of an aggressive bark beetle: Evidence of higher beetle reproduction in naïve host tree populations. Journal of Applied Ecology 47: 1036-1043.

DEAN, C. A. (2007): Genotype and population performances and their interactions for growth of coastal Douglas-fir in western Washington. Forest Science 53: 463-472.

DEAN, C. A. (2008): Genetic parameters of somatic clones of coastal Douglas-fir at $5 \frac{1}{2}$-years across Washington and Oregon, USA. Silvae Genetica 57: 269-275.

DeAN, C. A. (2009): Short note: Genotype-environment interactions for coastal Douglas-fir grown to 21 years across western Washington State, USA. Silvae Genetica 58: $39-42$.

Gilmour, A. R., B. J. Gogel, B. R. Cullis, S. J. Welham and R. Thompson (2010): ASReml User Guide Release 3.0. Vol VSN International; Hemel Hempstead, HP1 $1 \mathrm{ES}, \mathrm{UK}$.

Hansen, E. M., J. K. Stone, B. R. Capitano, P. Rosso, W. Sutton, L. Winton, A. Kanaskie and M. G. McWilliams (2000): Incidence and impact of Swiss nee- 
dle cast in forest plantations of Douglas-fir in coastal Oregon. Plant Disease 84: 773-778.

Hood, I. A. and M. O. KimberLey (2005): Douglas-fir provenance susceptibility to Swiss needle cast in New Zealand. Australasian Plant Pathology 34: 57-62.

Hood, I. A., C. J. Sandberg, C. W. BarR, W. A. Holloway and P. M. BRADBURY (1990): Changes in needle retention associated with the spread and establishment of Phaeocryptopus gaeumannii in planted Douglas-fir. European Journal of Forest Pathology 20: 418-429.

JoHnson, G. R. (2002): Genetic variation in tolerance of Douglas-fir to Swiss needle cast as assessed by symptom expression. Silvae Genetica 51: 80-86.

Knowles, R. L., L. Hansen, A. Wedding and G. Downes (2004): Evaluation of non-destructive methods for assessing stiffness of Douglas-fir trees. New Zealand Journal of Forestry 34: 87-101.

Knowles, R. L., M. O. Kimberley and I. A. Hood (2001): Swiss needle cast disease of Douglas-fir - impact on growth, Vol 142 pp. in Forest Health News edited by New Zealand Forest Research Institute, Rotorua, New Zealand.

KRAKowski, J. and M. U. Stoehr (2009): Coastal Douglasfir provenance variation: Patterns and predictions for British Columbia seed transfer. Annals of Forest Science 66: 811p1-811p10.

Krutovsky, K. V., J. B. St. Clair, R. Saich, V. D. Hipkins and D. B. NEALE (2009): Estimation of population structure in coastal Douglas-fir [Pseudotsuga menziesii (Mirb.) Franco var. menziesii] using allozyme and microsatellite markers. Tree Genetics and Genomes 5: 641-658.

Kurz, W. A., C. C. Dymond, G. Stinson, G. J. Rampley, E. T. Neilson, A. L. Carroll, T. Ebata and L. SAFranyiK (2008): Mountain pine beetle and forest carbon feedback to climate change. Nature 452: 987-990.

MACiAS FAuria, M. and E. A. Johnson (2009): Largescale climatic patterns and area affected by mountain pine beetle in British Columbia, Canada. Journal of Geophysical Research 114: G01012. DOI 10.1029/2008jg000760.

Maguire, D. A., D. B. Mainwaring and A. Kanaskie (2011): Ten-year growth and mortality in young Douglas-fir stands experiencing a range in Swiss needle cast severity. Canadian Journal of Forest Research 41: 2064-2076.

Matheson, A. C. and C. A. Raymond (1984): The impact of genotype $\mathrm{x}$ environment interactions on Australian Pinus radiata breeding programmes. Australian Forest Research 14: 11-25.

MilleR, J. T. and F. B. KNowles (1994): Introduced forest trees in New Zealand: Recognition, role and seed source. Forest Research Bulletin No. 124. No. 14. Douglas-fir Pseudotsuga menziesii (Mirbel) Franco. 37p.

MinistRy OF AGRICULTURE AND FoRESTRY (2011): A national exotic forest description as at April 15 2010. Retrieved 27 November, 2011, from http://www.maf.govt.nz/newsresources/publications.aspx?title=National $\% 20$ Exotic $\% 2$ 0Forest\%20Description.

NZ Wood (2011): Douglas-fir. Retrieved 27/11, 2011, from http://www.nzwood.co.nz/species/douglas-fir.
SAFranyiK, L., A. L. CARroll, J. RÉGnière, D. W. LANGOR, W. G. Riel, T. L. Shore, B. Peter, B. J. Cooke, V. G. NEALIS and S. W. TAYLOR (2010): Potential for range expansion of mountain pine beetle into the boreal forest of North America. Canadian Entomologist 142 415-442.

SAS Institute (2010): SAS Users Guide, Version 9.1. Cary, North Carolina.

Shelbourne, C. J. A. (1972). Genotype-environment interaction: its study and its implications in forest tree improvement. pp. 1-27. In: IUFRO Genetics-SABRAO Joint Symposia for the Advancement of Forest Tree Breeding, Tokyo, Japan. IUFRO.

Shelbourne, C. J. A., C. B. Low, L. D. GeA and R. L. KNOWLES (2007): Achievements in forest tree genetic improvement in Australia and New Zealand 5: Genetic improvement of Douglas-fir in New Zealand. Australian Forestry 70: 28-32.

Shelbourne, C. J. A., C. B. Low, R. McConnochie and M. D. WILCOX (2005): 50 years of tree improvement with New Zealand's "alternative" plantation species. IUFRO Breeding theory and progeny testing. Retrieved 27/11, 2011, from http://iufro.uncronopio.org/node/16.

Shore, T. L., J. E. Brooks and J. E. Stone (2004): Mountain Pine Beetle Symposium: Challenges and Solutions, 287 pp. in edited by October 30-31, 2003 ed. Natural Resources Canada, Canadian Forest Service, Pacific Forestry Centre, Victoria, BC, Canada; Kelowna, British Columbia.

Stone, J. K., I. A. Hood, M. S. WatT and J. L. KerRigan (2007): Distribution of Swiss needle cast in New Zealand in relation to winter temperature. Australasian Plant Pathology 36: 445-454.

SweEt, G. B. (1965): Provenance differences in Pacific Coast Douglas-fir. Silvae Genetica 14: 46-56.

Temel, F., G. R. Johnson and W. T. AdAms (2005): Early genetic testing of coastal Douglas-fir for Swiss needle cast tolerance. Canadian Journal of Forest Research 35: 521-529.

Temel, F., G. R. Johnson and J. K. Stone (2004): The relationship between Swiss needle cast symptom severity and level of Phaeocryptopus gaeumannii colonization in coastal Douglas-fir (Pseudotsuga menziesii var. menziesii). Forest Pathology 34: 383-394.

WatT, M. S., J. K. Stone, I. A. Hood and D. J. Palmer (2010): Predicting the severity of Swiss needle cast on Douglas-fir under current and future climate in New Zealand. Forest Ecology and Management 260: 2232-2240.

White, T. L. and K. K. ChInG (1985): Provenance study of Douglas-fir in the Pacific Northwest region. IV. Field performance at age 25 years. Silvae Genetica 34: 84-90.

Woods, A., K. D. Coates and A. Hamann (2005): Is an unprecedented dothistroma needle blight epidemic related to climate change? BioScience 55: 761-769.

WratT, D. and B. Mullan (2010): Climate Change Scenarios for New Zealand. Retrieved 4/12/2010, 2010, from http://www.niwa.co.nz/our-science/climate/information-and-resources/clivar/scenarios\#documentContent. 